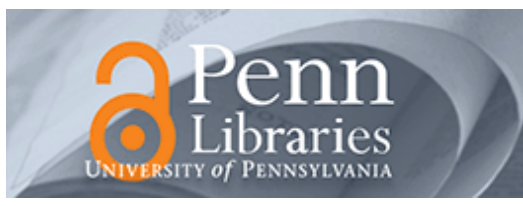

University of Pennsylvania ScholarlyCommons

Wharton Pension Research Council Working

Papers

Wharton Pension Research Council

$1-1-2003$

\title{
Cash Balance Pension Plan Conversions and the New Economy
}

Julia Lynn Coronado

Watson Wyatt Worldwide

Phillip C. Copeland

Follow this and additional works at: https://repository.upenn.edu/prc_papers

Part of the Economics Commons

Coronado, Julia Lynn and Copeland, Phillip C., "Cash Balance Pension Plan Conversions and the New Economy" (2003). Wharton Pension Research Council Working Papers. 438.

https://repository.upenn.edu/prc_papers/438

This paper is posted at ScholarlyCommons. https://repository.upenn.edu/prc_papers/438

For more information, please contact repository@pobox.upenn.edu. 


\title{
Cash Balance Pension Plan Conversions and the New Economy
}

\begin{abstract}
Many firms that sponsor traditional defined benefit pensions have converted their plans to cash balance plans in the last ten years. Cash balance plans combine features of defined benefit (DB) and defined contribution (DC) plans, and yet their introduction has proven considerably more controversial than has the increasing popularity of DC plans. The goal of this study is to estimate a hierarchy of the influences on the decision of a firm to convert its traditional defined benefit pension plan to a cash balance plan. Our results indicate that cash balance conversions have been undertaken in competitive industries with tight labor markets and can be viewed largely as a response to better compensate a more mobile labor force. Indeed, many firms appear to increase their pension liabilities through such conversions
\end{abstract}

\section{Disciplines}

Economics 


\title{
Cash Balance Pension Plan Conversions and the New Economy
}

\author{
Julia Lynn Coronado and Phillip C. Copeland
}

PRC WP 2003-22

\section{Pension Research Council Working Paper}

\author{
Pension Research Council \\ The Wharton School, University of Pennsylvania \\ 3641 Locust Walk, 304 CPC \\ Philadelphia, PA 19104-6218 \\ Tel: $215.898 .7620 \bullet$ Fax: 215.898 .0310 \\ Email: pre@wharton.upenn.edu \\ http://prc.wharton.upenn.edu/prc/prc.html
}

Pension Research Council Working Papers are intended to make research findings available to other researchers in preliminary form, to encourage discussion and suggestions for revision before final publication.

We thank Karen Dynan, Andreas Lehnert, Peter Orszag, and Karen Pence for helpful comments. The views expressed in this paper are those of the authors and do not necessarily reflect the views of the Federal Reserve Board or its staff. Opinions and errors are solely those of the authors and not of the institutions with whom the authors are affiliated. (C) 2003 Juilia Lynn Coronado and Phillip C. Copeland. All Rights Reserved. 


\title{
Cash Balance Pension Plan Conversions and the New Economy
}

\author{
Julia Lynn Coronado and Phillip C. Copeland
}

\begin{abstract}
$\underline{\text { Abstract }}$
Many firms that sponsor traditional defined benefit pensions have converted their plans to cash balance plans in the last ten years. Cash balance plans combine features of defined benefit (DB) and defined contribution (DC) plans, and yet their introduction has proven considerably more controversial than has the increasing popularity of DC plans. The goal of this study is to estimate a hierarchy of the influences on the decision of a firm to convert its traditional defined benefit pension plan to a cash balance plan. Our results indicate that cash balance conversions have been undertaken in competitive industries with tight labor markets and can be viewed largely as a response to better compensate a more mobile labor force. Indeed, many firms appear to increase their pension liabilities through such conversions.
\end{abstract}




\section{Cash Balance Pension Plan Conversions and the New Economy \\ Julia Lynn Coronado and Phillip C. Copeland}

\section{Introduction}

Many firms that sponsored traditional defined benefit (DB) pension plans have converted these plans to cash balance $(\mathrm{CB})$ pensions in recent years. While cash balance plans are legally classified as DB pensions, they are often referred to as hybrid plans because they combine features of defined benefit and defined contribution (DC) plans. We argue that in critical ways cash balance plans are most like DC plans, and thus, the popularity of these plans can be thought of as part of the broader trend toward DC-like pension offerings. The number of CB conversions is notable; we estimate that converted plans now hold more than 40 percent of all DB assets. In this paper, we examine the driving forces behind cash balance conversions, and in doing so shed light on the factors that underlie the general move towards DC pensions.

While the fraction of full-time workers covered by an employer-sponsored pension has remained fairly steady at just under 60 percent, the share of pension participants covered by DC pensions has grown from less than forty percent in the early 1980s to about 70 percent in the late 1990s (Employee Benefits Research Institute, 2002 and Department of Labor, 2002). Defined benefit and defined contribution pensions have fundamentally different characteristics in terms of benefit accrual over time, exposure to financial market risk, and portability across jobs. Understanding what has led to the dominance of DC plans in the pension landscape will in turn help determine the implications of this shift for the distribution and adequacy of retirement saving.

Some of the hypotheses that have been considered for the shifting nature of pension coverage include that the costs of complying with the regulations put in place by the Employee 
Retirement Income Security Act (ERISA) in 1974 made offering a DB plan prohibitively expensive. In addition, some change in coverage could also occur if the structure of production in the economy shifts such that workers move into industries where DC pensions are more commonly offered. Another hypothesis is that employers are trying to avoid the costs associated with generous DB plans when the workforce is aging, which would imply that the movement towards DC plans is reducing benefit generosity per worker. The increasing popularity of DC plans could reflect a greater level of financial sophistication among workers that has led them to demand more control over their portfolios. Finally, changes in production technology and labor market conditions could unravel the original motivations for offering DB pensions, which are characterized by back-loaded benefits that reward tenure and punish worker mobility.

Focusing on cash balance conversions has two advantages. First, empirically establishing the determinants of the shift towards DC pensions has been difficult because relatively little of the change in coverage has been the result of direct substitution where a firm terminates a DB plan and establishes a DC plan in its place (Papke, 1999). Declining DB coverage has often come as sponsoring firms themselves become smaller or disappear altogether, while increasing DC coverage has been among both firms that continue to sponsor DB plans and new firms. Cash balance conversions are an example of direct substitution within a single firm in which a traditional DB plan is replaced with a DC-type plan, thus allowing us to examine the determinants of substitution by comparing the characteristics of converters with non-converters.

Another reason that an examination of cash balance conversions is particularly illuminating is that they are regulated as DB plans under ERISA, and therefore the trend towards cash balance conversions suggests that factors other than regulatory burden are important in understanding the movement towards DC-like pension packages. 
The conversion of traditional DB plans to CB plans has proven to be quite controversial, leading to congressional hearings and legislative attempts to block the adoption of CB plans. Affected participants who stand to lose benefits under such conversions have been quite vocal, and the popular press has characterized $\mathrm{CB}$ conversions as an attempt by employers to reduce overall benefit generosity in a way that is not transparent to workers. It has also been suggested that firms would really like to terminate their DB plans but find it too costly to do so because of tax considerations. Meanwhile, companies undertaking these conversions have countered that they are actually trying to better compete for mobile employees who realize little pension wealth under traditional DB pensions due to their lack of portability and delayed accrual.

In this paper we construct a unique data set of firms who have undertaken cash balance conversions that allows us to estimate a hierarchy of factors driving the trend toward cash balance conversions. Our results indicate that cash balance conversions have not reduced overall benefit generosity at the firm level, although some redistribution may be occurring among individual employees. There is some evidence that tax considerations may play a role in a firm's decision to convert to a $\mathrm{CB}$ plan rather than terminate its existing DB plan. However, these conversions have generally been undertaken in competitive industries that are characterized by tight and highly mobile labor markets. Since mobile workers benefit most from such conversions, we conclude that this trend may have positive implications for the eventual retirement wealth of participants.

\section{Shifting Pension Coverage}

In order to understand the factors that underlie the trend away from DB pensions it is useful to first review the models that have been used to rationalize their role in the labor market. ${ }^{1}$ In contrast to DC plans, benefits in a DB pension do not accrue evenly over an employee's 
tenure; the most rapid period of benefit accrual occurs in the years just prior to retirement. The back-loaded nature of benefits in a DB pension plan thus imposes a capital loss on workers who leave the firm before retirement. Workers essentially post a bond with the firm by accepting this arrangement and forfeit the bond if they quit or are fired prior to retirement.

Firms are generally thought to offer such arrangements in order to enhance productivity by reducing turnover, encouraging work effort, and regulating retirement behavior. ${ }^{2}$ Reducing turnover may be desirable either because productive technology is enhanced by long-term commitments or team production, or because the firm has high training costs for new employees. A DB pension contract can also resolve inefficiencies that arise from moral hazard when the monitoring of worker effort is difficult or costly. The capital loss incurred by the employee when separating from the employer provides an incentive to work hard and invest in firmspecific human capital, thus boosting productivity. A pension is simply a tax efficient way for firms to design a productivity enhancing deferred compensation arrangement and also gives firms a lever to induce workers to leave later in life when productivity wanes in a way that avoids claims of age discrimination.

While the federal government regulates and insures private pension accruals, the fact that most benefits accrue at the end of an employee's tenure in traditional DB plans means that much of the pension agreement is an implicit contract between workers and firms during an employee's working years. Sponsoring firms can renege on future pension accruals at any time, although they would incur reputation costs in doing so that would likely lower employee work effort and inhibit the firm's ability to enter into such contracts in the future. Thus the gains firms realize from increased productivity due to the back loading of compensation and the costs they 
would incur from reneging on such promises serve as an enforcement mechanism for the implicit component of the pension contract.

Given a credible enforcement mechanism, employees will accept these terms in order to reap the higher lifetime pay that results from their increased productivity. Ippolito (1994) suggests that employees covered by DB pension contracts are also paid an indenture premium for foregoing the possibility of higher spot wages that may result from future job offers. The degree of wage tilt during the working years and the amount of the pension in his model depend on the size and likelihood of receiving an outside offer of employment. In contrast, DC plans are essentially a tax-favored saving account that is portable across jobs, and in which retirement wealth accumulates more evenly over an individual's working life.

Other reasons that workers may want pensions include the desire to earn tax-favored returns, or to realize economies of scale on the transaction costs of investment, although both of these goals can be realized in a DC plan as well as a DB plan. ${ }^{3}$ In a DB plan workers may also realize the opportunity to insure to some degree against mortality, inflation, macroeconomic, and disability risks through inter- and intra-generational risk sharing.

The aggregate statistics on pension coverage from a variety of sources show little change in pension coverage in the last three decades, with a growing share of workers covered by only DC plans. Arguably, the critical distinction between DC and DB pension plans is that there is little or no wealth loss associated with separating from an employer prior to retirement in a DC plan. While DC plans often have a vesting period and may feature graduated matching schedules in employer contributions that reward longevity, vesting generally occurs much sooner and benefits accrue much more evenly than in a DB plans. DC plans also offer control over investments and are generally more portable across jobs. 
A couple of recent papers have explored the factors that might lead such arrangements to break down within the implicit contracting theoretical framework that rationalizes the existence of DB pensions plans. Both Friedberg and Owyang (2002) and Balan (2003) suggest that these contracts could become unstable in the face of changes in production technology that led to a relatively higher return to general versus firm-specific human capital. Such a shift in production technology would lead to higher employee mobility and shorter average tenure, making the retention of employees with a $\mathrm{DB}$ contract prohibitively expensive even for firms that still realize a gain from longer tenure due to the higher probability employees face of receiving a more lucrative outside offer of employment. Indeed there is evidence to suggest that the return to general human capital has risen faster than the return to firm-specific human capital in recent years, particularly for new labor market entrants (Abowd, Lengermann, and McKinney, 2002). We might thus expect to see substitution away from traditional DB contracts in industries characterized by mobile, and perhaps also by younger, workers.

While the stylized facts on pension coverage suggest substitution of DC for DB pensions, and there are a number of hypotheses to explain this shift, much of the empirical work to date has focused on debating whether this substitution has in fact occurred. One branch of research uses household level data to assess the degree to which the sharp increase in DC wealth can be considered to be new saving, a finding that would be consistent with little direct substitution of DC for DB pensions. ${ }^{4}$ The results from this literature range from concluding that all of the increase in DC wealth is new saving to suggesting that none of the rise is new saving, thus preventing us from drawing much insight about the determinants of shifting pension coverage.

Another group of papers uses firm level data to examine the degree of substitution of DC for DB pensions. In the years immediately following the introduction of $401(\mathrm{k})$ plans, a number 
of studies concluded that a significant portion of the change in coverage was due to workers

moving to industries where DC plans were more commonly offered than DB plans. ${ }^{5}$ Papke (1999) used the same data for the period 1985-92 and found more direct substitution; a fifth of firms sponsoring DB pensions terminated these plans in favor of DC arrangements over this period. The focus of Papke's study was establishing that direct substitution was indeed taking place, and she did not explore the determinants of why some firms terminated their plans while others did not. However, the finding of direct substitution suggests a behavioral response by firms to changing production technology, demographics, or labor market conditions. Our analysis explores another channel of direct substitution; that of cash balance pension plans for a traditional DB arrangement, and we extend the analysis to establish the determinants of such substitution.

\section{Cash Balance Conversions: Issues and Evidence}

Cash balance plans combine features of defined benefit and defined contribution pension plans. Legally, cash balance plans are DB plans and are regulated as such under ERISA, and thus the Pension Benefit Guaranty Corporation (PBGC) insures benefits in such plans. Similar to a DC plan, however, employers regularly set aside a percentage of the employee's pay in an individual "account". The account is only a notional account and employees have no choice about how funds are invested. The employer invests the pooled assets of the pension plan and bears the investment risk, just as in a DB plan. The funds in the account earn a rate of return guaranteed by the employer, usually a rate linked to their discount rate, and the employee receives a periodic statement on their account status. Upon retirement, what the employee has accrued in their notional account is their retirement benefit and they can generally take it as a lump sum. 
Two features of cash balance plans make them more similar as a form of compensation to a DC pension: Benefits accrue earlier in a participant's career and employees can take a preretirement lump sum distribution from the plan if they leave the firm. Under both traditional DB and cash balance plans, employees accrue benefits in each year of work, and the present value of benefits accrued is called the projected benefit obligation, or PBO. The PBO under a typical cash balance pension plan and a traditional DB plan are shown in Figure 1. The PBO is the actuarial present value of benefits earned by an employee for service rendered prior to that date plus projected benefits attributable to future salary increases. In the chart, the age of an employee is on the horizontal axis and the vertical axis measures multiples of the employee's annual salary. The kink in the PBO under the traditional DB plan is when the employee qualifies for the early retirement subsidy, a feature common in DB plans but not in cash balance plans. Under the cash balance plan, the value of the pension right is larger at earlier ages and can be withdrawn by employees if they change jobs. ${ }^{6}$

Figure 1 here

As discussed above, the deferred accrual--or back-loading of benefits--under traditional DB plans is an inducement for employees to stay with the firm, since they forfeit a significant amount of future compensation if they leave. The defining characteristic of cash balance plans is that they remove the penalty to the employee for changing firms through earlier benefit accrual and portability of benefits.

The first company to convert its traditional DB pension plan to a cash balance plan was Bank of America in the mid 1980s. However, the popularity of cash balance conversions really took root in the mid-1990s. By 1998, approximately eleven percent of all DB plans had converted to cash balance plans. Converting companies were generally larger; 24 percent of 
S\&P 500 firms with DB pensions had converted their pension plans by 1998 . Converted plans at that time held about 30 percent of the assets and cover 25 percent of the employees covered by DB pension plans. However, most converting plans had grandfathering provisions that allowed older workers to remain under the provisions of the traditional DB plan, which would mean that some assets and employees in converted plans are still associated with the old DB plans.

Most cash balance conversions were undertaken with little fanfare. The exception was IBM, whose conversion catapulted the cash balance trend into the media and Congressional spotlight. Cash balance conversions were characterized in the media as an example of corporate greed; a way to reduce benefits generosity in a way that employees did not fully understand. An examination of the PBOs graphed in chart 1 illustrates that any employee who places a high probability on staying with the same firm until retirement and is switched from a traditional DB pension plan to a cash balance plan will generally take a significant hit to their expected future retirement wealth. However those who place a low probability on staying with the firm until retirement will realize a greater pension benefit under a cash balance plan.

It has been suggested that employers are reneging on the implicit component of their traditional DB arrangements through cash balance conversions (Ippolito, 2001; Gold, 2003). This is certainly plausible given the slower accrual under cash balance plans prior to retirement and the fact that pension regulations only require employers to pay what has been accrued to date. This would be feasible if the employers undertaking these conversions have relatively strong bargaining positions and are looking to reduce costs; perhaps they are facing an older population nearing their period of rapid benefit accrual. However, these employers would incur reputation costs and potentially reductions in productivity. Thus, many of these conversions have included granfathering provisions that allow employees that place a high probability on 
staying to remain in the old plan while moving younger employees to the cash balance plan. This is a potentially benefit increasing proposition for employers and would make sense if they have relatively weak bargaining power and whose employees place a lower probability on staying with the firm.

Regardless of whether or not the firm is seeking to renege on their implicit contracts with workers, in lieu of a CB conversion they could simply terminate their DB plan and establish a DC pension in its place. Ippolito (2001) suggests that is precisely what firms who undertake these conversions would like to do. He argues that firms do not do so because their pension plans are overfunded and they would face stiff tax penalties on their excess assets. The tax on excess assets in a terminated plan, known as the reversion tax, was raised to 50 percent in 1990 , from 15 percent. A cash balance conversion is a way of establishing a DC-like pension plan while avoiding the reversion tax. Niehaus and $\mathrm{Yu}$ (2002) examine the reversion tax hypothesis using firm level data, and find that most firms undertaking conversions are profitable and had overfunded pension plans on the eve of conversion. They conclude that firms might otherwise terminate their DB plan in favor of a DC plan in the absence of the stiff tax penalties on excess assets, but that firms were not necessarily undertaking these conversions in order to cut benefits. Much of the empirical work on cash balance conversions to date has focused on their redistributive consequences. One group of papers used profiles of workers with different wage and tenure patterns to simulate winners and losers under several actual conversions (Brown et al., 2000; Clark and Schieber, 2000; Clark and Schieber, 2001). The main findings of these studies were that pension wealth is transferred from single jobholders to multiple jobholders, and that the elimination of early retirement subsidies is the primary source of benefit loss to single jobholders. Another paper by Johnson and Ucello (2001) used data from the Health and 
Retirement Survey and concluded that pension wealth would be more equally distributed if cash balance plans had been the norm for the current generation nearing retirement, with multiple job holders gaining and single job holders losing pension wealth. The results of these papers are suggestive of the idea that a shift in labor market mobility is important in understanding the move away from traditional DB plans.

\section{Empirical Analysis}

In order to estimate a hierarchy of the influences on the decision of firms to convert their traditional defined benefit pension plans to cash balance plans, we construct a data set that combines firm level and pension plan data with industry-level data on labor market conditions. We can distinguish between motivations arising from tax avoidance, the desire to cut costs through a reduction in benefits, and attempts to compete for mobile workers.

We proceed in two stages. In the first stage we look at whether firms reduce benefits through cash balance conversions, as well as the extent to which this trend is driven by tax considerations. We use detailed data before and after conversion on the finances of a relatively small number of individual pension funds for which we could identify the conversion date. In the second stage we use a broader analysis of all S\&P 500 firms that sponsor a DB pension plan and include data on industry-specific labor market conditions that allow us evaluate the influence of labor market dynamics along with some of the potential determinants of the probability that a firm will convert its DB pension into a cash balance plan.

Stage One: Benefit Generosity and the Reversion Tax Hypotheses

In order to test whether a cash balance conversion reduces the overall generosity of the pension plan, we look at the forward-looking measure of a pension plan's liability before and after a conversion. We use the projected benefit obligation, which was described above and 
graphed in chart 1 . The PBO is the actuarial present value of benefits earned by employees to date incorporating assumptions about how the value of those benefits will increase over time due to future salary growth. Since the PBO only measures accrued benefits, and not the value of the pension if the employees stay until retirement, it will not capture the full extent to which the firm is appropriating the pension bonds of its employees. However, because the PBO takes into account assumptions about future salary growth, it is always greater than the accumulated benefit obligation that is insured by federal pension regulation and, thus, better captures changes in the overall benefit generosity of the plan. If firms are seeking to reduce benefits generosity, the PBO of the pension plan will decline upon conversion. Alternatively, if firms allow employees who are closer to retirement to choose to stay in the plan while shifting newer employees to the cash balance plan, the PBO will likely increase upon conversion.

The testable implication of the hypothesis that the decision to switch to a cash balance pension plan instead of terminating a DB plan is driven by tax considerations is that firms who switch to cash balance plans should be overfunded prior to conversion. The relevant funding for tax law is determined by the market value of plan assets relative to the accumulated benefit obligation. However, the data on ABOs is sparse, as the accounting standards that govern pension disclosure do not require firms to report the $\mathrm{ABO}$ in their financial statements so we use a funding ratio based on the PBO. If a plan is overfunded based on the PBO it is certainly overfunded based on the ABO, thus if we find that most converting firms are overfunded based on the $\mathrm{PBO}$ we can conclude that tax considerations may be an important influence in their decisions. However a firm could be underfunded on a PBO basis but overfunded on an ABO basis. Thus, if we find that plans are underfunded prior to conversion this does not conclusively suggest that tax considerations play no role. 
The examination of funding ratios and changes in PBOs after a cash balance conversion is simple in concept, however the task is made difficult by the fact that there are no disclosure requirements for a conversion. Thus, we first identified firms who had converted their traditional DB pensions to cash balance plans as of 1998 using the results of a survey conducted by Pensions and Investments, which we augmented using sources in the benefits consulting industry, and information included in 10k reports. Because 10k filings with the Securities and Exchange Commission were one of our primary sources of data, we focused on publicly traded firms in the S\&P 500 resulting in 75 firms who had converted their pensions to cash balance plans before 2000. To determine the date of conversion, we then searched the financial statements of these firms. We identified the date of conversion and were able to obtain information on funding and pension liabilities in the year before, the year of, and the year after conversion for 32 firms, or less than half of the total sample.

The firms in our sample are listed by industry in the first column of Table 1. The year they converted to a cash balance plan is shown in the second column. The earliest converters in our sample were RJR Nabisco and Bellsouth in 1993, while fully one quarter of the sample converted in 1999. The funding ratio, calculated as the market value of assets over the PBO, in the year prior to conversion is shown in the third column. More than a third of the firms in the sample are more than 5 percent overfunded in the year prior to conversion, suggesting that terminating their existing DB plan would involve a significant loss of money. Another third of the sample is more than five percent underfunded in the year prior to conversion. However, this funding is based on the $\mathrm{PBO}$, while the funding relevant for tax law is based on the $\mathrm{ABO}$. For this latter group of firms, we were able to find their ABO in 1994 and calculate an ABO-based funding ratio. Indeed, half of this group was in fact overfunded based on their ABO in 1994, a 
year that preceded all of their conversions. Given financial market conditions in the years between 1994 and their conversion, it is likely that these firms were also overfunded based on their ABO in the year prior to conversion. Thus, it is quite possible that in the absence of overfunding, these firms may have decided to terminate their existing DB plans and establish a DC plan in its place.

\section{Table 1 here}

The percentage change in the PBO between the year after conversion and the year prior to conversion is shown in the fourth column. Pension liabilities increased upon conversion for two thirds of the sample, with increases of more than 10 percent for half of these firms. If a firm wanted to disguise a decrease in benefits resulting from a cash balance conversion, it could decrease its assumed discount rate in the year of conversion to raise its post-conversion obligations. Of course, discount rates must track bond market conditions, and rates were generally falling over this period. So a firm could reduce its discount rate after conversion for sound economic reasons; indeed, as shown in the last column, half of the sample did decrease their assumed discount rate between the year prior and the year following conversion. In any case, we want to be sure our conclusions about benefit generosity are not driven by changes in discount rates.

We estimated how changes in the discount rate affect changes in the PBO by regressing percentage changes in the PBO on changes in the discount rate in the two years prior and the two years following conversion. The resulting coefficient suggested that a one percentage point decrease in the discount rate would be associated with a five percentage point rise in the PBO. We use this coefficient to adjust the change in reported $\mathrm{PBO}$, and the adjusted measure is reported in the fifth column. The conclusions do not change: the majority of firms increased 
their liabilities as a result of their conversion. If firms were simply appropriating the pension bonds of their workers than they would provide employees with an initial cash balance valued at the $\mathrm{ABO}$, and the $\mathrm{PBO}$ would decline upon conversion. It appears that many firms may have allowed longer tenure employees to remain under the old plan, or provided them with an initial cash balance of equivalent value, while moving employees with fewer years of service to the new plan.

One concern in drawing conclusions based on the sample of firms for which we could identify conversion dates is that there may be a selection bias; firms who are most generous to employees in their cash balance conversions may be more likely to disclose information about the conversion in the footnotes to their financial statements. Testing for this selection bias is difficult given that it would require comparing characteristics of the firms prior to the conversion. However, we did compare the firms using data from 1998 and found that those firms for which we could identify conversion dates did not significantly differ from the other converting firms in terms of the value of plan assets, the industry distribution, or the funding ratio. Another check on the degree to which selection is affecting our results in the first phase will be the consistency of the conclusions between the first and second phases of the analysis. Stage Two: The Influence of Industry Labor Market Conditions

The evidence presented thus far suggests that the reversion tax on excess funding may have led firms to choose cash balance plans over terminating their traditional DB pension and establishing a 401k plan in its place; however it does not appear that most converters are necessarily reneging on the promised value of pension benefits. Under implicit contract theory, firms would suffer reputation costs and current productivity if they chose to appropriate the pension bonds posted by their employees. While changes in labor market conditions could lead 
the traditional DB contract to break down, it does not necessarily follow that the level of compensation will also decline. In this phase of our analysis we broaden our sample to include all firms in the S\&P 500 that sponsor a DB pension plan and incorporate industry-level data on labor market conditions. We estimate the determinants of the probability that a firm will convert its traditional DB plan to a cash balance plan including the pension plan's financial position, industry demographics, and labor market dynamics.

Our sample consists of 319 firms, 75 of which had converted their pension plan to a cash balance plan by 1998 . We compile a number of industry characteristics from a variety of data sources, where industry is defined at the level of 2-digit SIC codes. The values of the industry measures are shown in Table 2. The first column of shows the percent of DB pensions in the industry that have been converted to cash balance plans. The identification of these firms was the same as in the first phase of the analysis. The rate of cash balance conversions is highly concentrated by industry: it is as low as zero and as high as 55 percent. The degree of concentration raises questions about explanations for the declining popularity of DB pensions that have relied on the regulatory burden of these plans or the desire by firms to cut benefits across the board: Neither of these hypotheses would necessarily translate into different conversion rates across industries. The percent of firms in the industry with a DB pension was derived for 1998 using data from Compustat and is shown in the second column. The sponsorship rate of DB pension plans also differs across industries, ranging from 25 percent for construction to 90 percent for utilities and sanitation services.

\section{Table 2 here}

Capturing industry-specific labor market mobility is key to testing the some of the predictions of implicit contract models. There are a number of reasons workers could change 
jobs, including cyclical factors in which workers are hired or fired due to the trajectory of business activity in a sector. Alternatively, workers could be hired or fired more frequently if they have relatively little bargaining power and, hence, job security. One of the more difficult to measure and frequently overlooked measures of worker mobility occurs when workers have relatively strong bargaining power and are able to change jobs without any period of unemployment. A measure of this kind of mobility, referred to as the employer-to-employer (EE) rate of job change, was developed by Fallick and Fleischman (2001) using data from the Current Population Survey. The EE rate is shown by industry in the third column of Table 2. The measure represents the percent of workers in an industry who left their jobs for other jobs (in the same or a different industry) without a spell of unemployment. Shifts in this type of worker mobility would likely lead to a breakdown in the traditional DB contract as employees place a lower probability on staying with the firm and therefore place little value on the existing DB pension promise. In order to keep these employees, firms would have to increase the value of the DB pension beyond the point that it is worth the enhanced productivity from longer tenure. The EE rate ranges from 1.3 percent or workers leaving their employers for another job in the transportation industry to 4.3 percent of workers in technology and business services.

The fourth column of Table 2 shows the percent of employees in an industry that are over 45 years of age in 1998, published by the Bureau of Labor Statistics. This measure gets at both the benefits generosity and labor market mobility hypotheses. If the employer is facing a large number of workers who are nearing their most rapid phase of benefits accrual and wants to avoid the associated increases in pension costs, then a cash balance plan could be a mechanism for reducing future pension accruals. Alternatively if the employer has a relatively young and mobile workforce that places low probability of staying until retirement then a cash balance 
conversion could prove a more valuable form of compensation to these employees. The cost saving in future pension accruals could be relatively little or they could actually increase. Ideally we would have the age distribution of employees at the firm level; however, we are assuming the firm's distribution will be correlated with the industry average.

Unemployment rates for 1998 are displayed by industry in the last column of the table, also obtained from the Bureau of Labor Statistics. ${ }^{7}$ The unemployment rate is a proxy for the relative bargaining power of employers and employees. If there was a lot of slack in the labor market, firms might have relatively strong bargaining positions and would perhaps be able to appropriate the pension bonds of their employees. However, if firms face tight labor markets they would have less ability to cut benefits. The unemployment rate in this period ranged from roughly $2-1 / 2$ percent in the utilities and sanitation services, communication, and finance, insurance and real estate industries to $7-1 / 2$ percent in the construction industry. The simple correlations of these industry-level variable are presented in Table 3 . The rate of cash balance conversions in an industry is negatively correlated with the DB sponsorship rate in the same industry. Thus, the less likely a firm's competitors are offering a DB plan, the more likely it is that a firm with an existing DB plan will convert it to a cash balance plan.

Conversions are positively correlated with the EE rate, so that mobile employees are associated with a higher fraction of cash balance offerings. Relatively older workers and greater labor market slack are both negatively correlated with the rate of cash balance conversions. Thus, the simple correlations are consistent with an implicit contract story of firms undertaking cash balance conversions to better compete for younger, more mobile workers in tight labor markets. Table 3 here 
We sort through the various influences in a multivariate regression framework. We know all firms in the S\&P 500 who converted their traditional DB plan to a cash balance plan as of 1998. However, some firms converted their plans after 1998, while still others may convert their plans in the future. Ideally we could estimate a hazard rate of the probability that a firm will convert its pension to a cash balance plan taking into account dynamic information on the variables of interest and the conversion dates of those plans that already made the switch. Unfortunately we do not know the conversion dates for this broader sample and are unable therefore to estimate a dynamic model. Instead, we estimate a probit model of the probability that a firm with an existing DB pension plan converted to a cash balance plan, using both the sample that had converted as of 1998, as well as those that we know have converted since that time.

In essence this approach assumes that there is no duration effect, that is, the probability of cash balance conversion is unaffected by how long the firms have maintained their traditional DB plans. There is no intuitive reason to expect a duration effect; rather the probability of conversion is likely influenced by current labor and financial market conditions. The validity of our results thus relies on the relative cross-sectional patterns of the independent variables remaining stable over time. We estimate the model measuring the explanatory variables as of 1998, when we know that most of these firms had already converted, as well as 1994 when we know both anecdotally and from our first stage analysis that the conversion wave was just getting underway.

Explanatory variables include the industry-level measures described above, which are designed to measure the effect of labor market conditions on the firm's conversion decision. To capture scale effects that may result from the fixed costs associated with any reform to a pension 
plan, we include the log of plan assets. We also include the (PBO-based) funding ratio, which may be an important influence if the firm's decision to convert to a cash balance plan rather than terminate the DB plan in favor of a DC plan is driven by tax penalties on excess assets. Not knowing the conversion date implies that the tax law influence will be potentially poorly measured, as the funding ratio will only be important in the periods prior to the conversion. However, this is a cross-sectional analysis and thus the estimated coefficient will measure the effect of the relative funding positions among firms, which is not very likely to change much over time and therefore should capture to some extent the degree to which the financial position of the plan influenced the conversion decision. The results are presented in Table 4 where the estimated marginal effects calculated at the means of the variables of interest are shown and tstatistics are given below the estimated marginal effects in parentheses.

\section{Table 4 here}

In the first column results are presented where the variables of interest are measured as of 1998 and no industry dummies are included. The only variables that have significant explanatory power for the probability that a firm converted its pension plan to a cash balance plan are the log of plan assets and the industry unemployment rate. The coefficient on plan assets suggests that scale effects are important, the larger the plan, the more likely is a conversion. The coefficient on the industry unemployment rate suggests that conversions are more likely in tighter labor markets. The percent of firms in the industry with a DB pension, the funding position of the plan, and the rate that employees in the industry change jobs without a spell of unemployment do not significantly affect the probability of conversion in this specification. The pseudo R-squared, which is the analogous measure for maximum likelihood models to the coefficient of determination, is presented at the bottom of the table. A value of 
zero corresponds to predictive power equivalent to that of regressing the independent variable on a constant, whereas a value of one implies the model has perfect predictive power. The specification in the first column has fairly modest predictive power.

We add industry dummies to this specification and the results are presented in the second column of the table, although the coefficients on the industry dummies are not presented. The explanatory variables that measure labor market conditions vary only by industry, so that including industry dummy variables is essentially allowing for a nonlinear effect of these measures. It would also imply that a correct interpretation of the marginal effect of industry labor market measures would require incorporating the coefficient on the dummy variable. However, given the limitations of the cross-sectional analysis we are focused on the sign and relative importance of the independent variables and do not put too fine a point on the estimated marginal effects. The size of the plan continues to have a positive and significant effect on the probability of conversion in this specification, while the effect of the industry unemployment rate, while still indicating a positive effect from tight labor markets, is no longer significant. The employer-to-employer rate also has a positive and significant effect on the probability of conversion, indicating that more mobile workers influence firms to change their pension offerings. The point estimate on the percent of the labor force over 45 in this all other specifications is negative, indicating that a higher fraction of older workers reduces the probability of conversion, contradicting the idea that a driving force behind the popularity of cash balance plans is an aging workforce. Funding status and the fraction of DB offerings in the industry continue to be statistically unimportant, and the point estimates are quite small. Overall, the explanatory power of the regression improves considerably when the industry dummy variables are included. 
We know that most of the firms in our sample that converted to a cash balance plan did so by 1998 , and that most of them did so after 1994. Thus far our variables of interest have been measured in 1998, however it is the financial and labor market conditions prior to their conversion will be the relevant influence on their conversion decision. It is also possible that if the reduction of penalties to leaving an employer inherent in a cash balance plan facilitated mobility within an industry, we could have a problem if endogeneity in the employer to employer rate in 1998. In the third column we present the results of measuring the variables of interest in 1994. The third column shows the results without industry dummy variables, which are qualitatively similar to the regressions using 1998 data; plan size, greater mobility and tighter labor markets lead to a greater probability that a firm will convert its pension to a cash balance plan, while funding, age of workers, and the percent of other firms in the industry that offer a DB plan are not significant determinants of this decision. The fit of the regression is better than that of the comparable specification using 1998 data shown in the first column.

The last column in the table shows the results from using the plan financial and labor market variables as of 1994 and including industry dummy variables. The fit of the regression is better than that of the other three specifications. The size of the plan is still a significant determinant of the probability of cash balance conversion and the point estimate is similar to the other specifications. The unemployment rate has an economically and statistically significant effect on the conversion decision, as does the employer-to-employer rate. The fraction of the labor force over 45 has significant explanatory power in this regression and is negatively associated with cash balance conversions. The percent of firms with a DB plan is also significant and suggests that the greater the fraction of competitors with a DB plan, the less likely a firm is to convert its plan to a cash balance plan. 


\section{Conclusions}

In this paper, we have shed light on the motivations of firms that convert their traditional DB pensions to cash balance plans. Our results suggest that, while avoidance of the reversion tax may have led some firms to choose cash balance conversions over termination of their traditional DB plan, it does not appear that most firms are seeking to reduce benefit generosity. Indeed, given the tight labor markets in which these converters are operating, it is likely that appropriating the pension bonds of employees would be a costly strategy in terms of recruitment and retention efforts. Cash balance conversions appear to be largely driven by labor market conditions. In particular, industries with younger, more mobile workers and tighter labor markets have a greater concentration of conversions. Worker mobility may have made retention through traditional DB arrangements prohibitively expensive. In addition, productivity in these industries may have become less dependent on long-term contracts with workers.

Because cash balance conversions directly substitute a DC-like pension for a traditional DB plan, they suggest that that regulatory burden is not the only force behind the move to more portable pensions. Nor do these results support the notion that firms are reducing the benefits of an aging workforce. Rather the move toward DC-like pensions is likely the result of increased worker mobility. While many workers who planned to stay with a firm that previously offered a traditional DB arrangement will lose expected benefits through a cash balance conversion, the earlier accrual and portability of benefits will better facilitate the accumulation of retirement wealth for the majority of workers affected by these conversions. However, these results suggest that we should not necessarily expect to eventually see all DB pensions converted to cash balance plans. Certain industries may still rely on productive technology that is enhanced by long tenure, and deferred compensation may still be an efficient way to achieve this goal. 


\section{References}

Abowd, John M., Paul A. Lengermann, and Kevin L. McKinney. 2002. "The Measurement of Human Capital in the U.S. Economy.” U.S. Census Bureau Longitudinal EmployerHousehold Dynamics Technical Paper No. TP-2002-10.

Balan, David J. 2003. “Have Lazear-Style Implicit Contracts Disappeared?” Federal Trade Commission Working Paper 256.

Brown, Kyle, Gordon Goodfellow, Tomeka Hill, Richard Joss, Richard Luss, Lex Miller, and Sylvester Schieber. 2000. The Unfolding of a Predictable Surprise: A Comprehensive Analysis of the Shift from Traditional Pensions to Hybrid Plans. Bethesda: Watson Wyatt.

Choi, James J., David Laibson, Bridgitte Madrain, and Andrew Metrick. 2001. “Defined Contribution Pensions: Plan Rules, Participant Decisions, and the Path of Least Resistance." Tax Policy and the Economy. NBER Working paper 8655.

Clark, Robert L., and Sylvester J. Scheiber. 2001. "An Empirical Analysis of the Transition to Hybrid Pension Plans in the United States.” Washington, D.C. The Brookings Institution. . 2000. "Taking the Subsidy Out of Early Retirement: Converting to Hybrid

Pensions.” Pension Research Council Working Paper 2000-9.

Employee Benefits Research Institute. 2002. “An Analysis of the Retirement and Pension Plan Coverage Topical Module of the SIPP.” Issue Brief 245.

Engen Eric, William Gale, and John Karl Scholz. 1994. “Do Saving Incentives Work?” Brookings Papers on Economic Activity (1): 85-179.

Even, William, and David Macpherson. 1996. "Employer Size and Labor Turnover: The Role of Pensions.” Industrial Labor Relations Review 49(4): 707-28. 
. 2003. "Benefits and Productivity." In Benefits for the Workplace of the Future, eds.

Olivia S. Mitchell, David S. Blitzstein, Michael Gordon, and Judith F. Mazo.

Philadelphia: University of Pennsylvania Press: 43-57.

Fallick, Bruce C., and Charles A. Fleischman. 2001. "The Importance of Employer-to-Employer Flows in the U.S. Labor Market.” Finance and Economics Discussion Series Working Paper 2001-18.

Friedberg, Leora and Michael T. Owyang. 2002. "Explaining the Evolution of Pension Structure and Job Tenure.” Federal Reserve Bank of St. Louis Working Paper 2002022A.

Gold, Jeremy. 2001. "Economic Design of Cash Balance Pension Plans.” Unpublished paper presented at the Society of Actuaries Meeting, Dallas, Texas. http://users.erols.com/jeremygold/papers.html

Gustman, Alan L., Olivia S. Mitchell, and Thomas Steinmeir. 1994. "The Role of Pensions in the Labor Market: A Survey of the Literature." Industrial and Labor Relations Review 47(3): 417-438.

Gustman, Alan L. and Thomas L. Steinmeier. 1992. "The Stampede Toward Defined Contribution Pension Plans: Fact or Fiction?” Industrial Relations 31(2): 361-69.

Hutchens, Robert. 1989. “Seniority, Wages, and Productivity: A Turbulent Decade”. Journal of Economic Perspectives, 3(4): 49-64.

Ippolito, Richard A. 2001. "Issues Surrounding Cash Balance Plans." Benefits Quarterly Third Quarter 2001:30-45. . 1995. "Toward Explaining the Growth of Defined Contribution Plans." Industrial Relations 34(1): 1-20. 
. 1994. "Pensions and Indenture Premia" Journal of Human Resources 29(3): 795-812.

Johnson, Richard W. and Cori E. Uccello. 2002. "Can Cash Balance Pension Plans Improve Retirement Security for Today's Workers?” The Urban Institute Retirement Project Brief 14.

Kruse, Douglas L. 1995. "Pension Substitution in the 1980s: Why the Shift Toward Defined Contribution?" Industrial Relations 34(2): 218-241.

Laibson, David I., Andrea Repetto, and Jeremy Tobacman. 1998. "Self-Control and Saving for Retirement”. Brookings papers on Economic Activity (1): 91-196.

Lazear, Edward P. 1979. “Why Is There Mandatory Retirement?” Journal of Political Economy 87(6): 1261-84.

Mitchell, Olivia S., 1990. “Aging, Job Satisfaction, and Job Performance” In An Aging Workforce, eds. I. Bluestone, R. Montgomery, and J. Owen. Detroit: Wayne State University Press: 242-72.

Neihaus, Gregory, and Tong Yu. 2000. "Cash Balance Plan Conversions: An Implicit Contract Perspective." University of South Carolina.

Pence, Karen. 2002. “401(k)s and Household Saving: New Evidence from the Survey of Consumer Finances" Finance and Economics Discussion Series Working Paper 2002-06.

Poterba, James M., Steven F. Venti, and David A. Wise. 2001. “The Transition to Personal Accounts and Increasing Retirement Wealth: Macro and Micro Evidence.” National Bureau of Economic Research Working Paper 8610. . 1995. "Do 401(k) Contributions Crowd Out Other Private Saving?" Journal of Public Economics 58: 1-32. 
Papke, Leslie E. 1999. “Are 401(k) Plans Replacing Other Employer-Provided Pensions?” Journal of Human Resources 34(2): 346-368.

Pensions \& Investments. 1999. "Special Report: Cash Balance Plans."

US Department of Labor. 2002. "Abstract of the 1998 Form 5500 Annual Reports." 


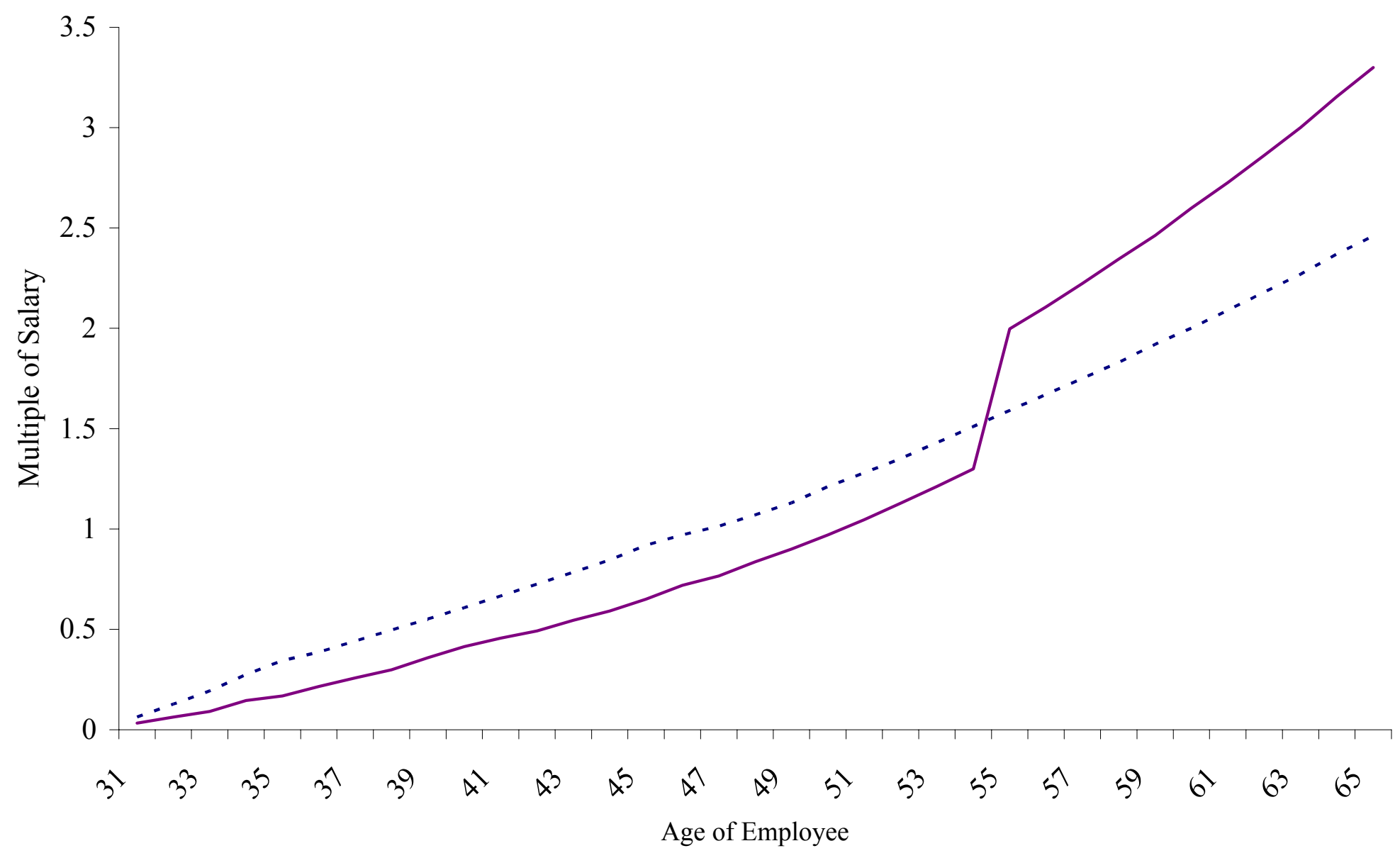

$$
\text { - - - - Cash Balance T Traditional DB }
$$

Figure 1. Projected Benefit Obligation Under Different Pension Plans 
Table 1. Funding Status Prior to Cash Balance Conversion and Change in Benefits

\begin{tabular}{|c|c|c|c|c|c|}
\hline & \multirow{2}{*}{$\begin{array}{c}\text { Year of } \\
\text { Conversion }\end{array}$} & \multirow{2}{*}{$\begin{array}{r}\text { PBO Funding } \\
\text { Level Prior to } \\
\text { Conversion } \\
\end{array}$} & \multicolumn{2}{|c|}{ Change in $\mathrm{PBO}$} & \multirow{2}{*}{$\begin{array}{r}\text { Change in } \\
\text { discoun } \\
\text { rate }\end{array}$} \\
\hline & & & unadjusted & adjusted & \\
\hline \multicolumn{6}{|l|}{ Manufacturing } \\
\hline AK STEEL HOLDING CORP & 1995 & 90.1 & 14.9 & 13.6 & -0.25 \\
\hline BADGER METER INC & 1997 & 116.0 & 17.5 & 14.9 & -0.5 \\
\hline COMMONWEALTH INDUSTRIES INC & 1998 & 90.6 & 6.7 & 9.2 & 0.5 \\
\hline DONALDSON CO INC & 1999 & 102.3 & 8.3 & 12.1 & 0.75 \\
\hline GOODYEAR TIRE \& RUBBER CO & 1998 & 99.2 & 35.6 & 38.2 & 0.5 \\
\hline OWENS CORNING & 1996 & 100.5 & 22.8 & 21.5 & -0.25 \\
\hline \multicolumn{6}{|l|}{ Energy } \\
\hline ALLIANT ENERGY & 1998 & 111.6 & 1.4 & 4.0 & 0.5 \\
\hline UKE ENERGY CORP & 1997 & 74.7 & 19.5 & 15.6 & -0.75 \\
\hline EL PASO ENERGY PARTNERS & 1997 & 98.6 & 6.1 & 1.0 & -1 \\
\hline ENRON CORP & 1995 & 105.7 & -7.1 & -9.7 & -0.5 \\
\hline NIGARA MOHAWK HOLDINGS & 1999 & 111.1 & -9.1 & -3.9 & 1 \\
\hline \multicolumn{6}{|l|}{ Telecommunications } \\
\hline AT\&T CORP & 1998 & 141.7 & -11.1 & -7.3 & 0.75 \\
\hline BELLSOUTH & 1993 & 115.9 & -1.5 & 1.0 & 0.5 \\
\hline \multicolumn{6}{|l|}{ SOUTHERN NEW ENGLAND } \\
\hline TELECOM & 1996 & 118.1 & -11.5 & -11.5 & 0 \\
\hline \multicolumn{6}{|l|}{ Finance, Insurance, and Real Estate } \\
\hline AETNA INC & 1999 & 97.1 & -4.2 & -0.3 & 0.75 \\
\hline ALLMERICA FINANCIAL CORP & 1995 & 103.1 & -6.2 & -14.0 & -1.5 \\
\hline AMERICAN EXPRESS & 1995 & 84.3 & 12.3 & 10.5 & -0.35 \\
\hline CITIGROUP INC & 1996 & 94.1 & 6.9 & 5.6 & -0.25 \\
\hline NATIONAL CITY CORP & 1998 & 135.2 & 1.1 & 0.9 & -0.05 \\
\hline PNC BANK & 1999 & 87.5 & -1.2 & 2.7 & 0.75 \\
\hline SAFECO CORP & 1999 & 112.1 & -1.8 & 0.8 & 0.5 \\
\hline WELLS FARGO \& CO & 1999 & 102.5 & 6.8 & 11.9 & 1 \\
\hline \multicolumn{6}{|l|}{ Technology and Business Services } \\
\hline ELECTRONIC DATA SYSTEMS & 1998 & 94.6 & 27.4 & 25.9 & -0.3 \\
\hline INTL BUSINESS MACHINES & 1999 & 114.1 & 0.1 & 4.0 & 0.75 \\
\hline TEKTRONIX INC & 1998 & 95.6 & 16.5 & 12.3 & -0.8 \\
\hline XEROX CORP & 1999 & 99.0 & 2.7 & 2.7 & 0 \\
\hline \multicolumn{6}{|l|}{ Other Industries } \\
\hline AVON PRODUCTS & 1998 & 88.3 & 3.3 & 0.2 & -0.6 \\
\hline CSX CORP & 1997 & 81.0 & 17.8 & 12.7 & -1 \\
\hline GENESCO INC & 1996 & 65.5 & 11.3 & 6.1 & -1 \\
\hline HANNAFORD BROS & 1998 & 105.0 & 9.5 & 9.5 & 0 \\
\hline RJR NABISCO & 1993 & 88.5 & 0.3 & 1.5 & 0.25 \\
\hline SUBURBAN PROPANE PARTNERS & 1998 & 122.8 & -3.6 & -2.3 & 0.25 \\
\hline \multicolumn{5}{|c|}{ Firms who were overfunded (bases on PBO) prior to conversion } & $50 \%$ \\
\hline \multicolumn{5}{|c|}{ Firms who reduced (adjusted) PBO through conversion } & $22 \%$ \\
\hline
\end{tabular}


Table 2. Industry Level Data of Employee Characteristics and Benefit Characteristics in 1998

\begin{tabular}{|c|c|c|c|c|c|}
\hline Industry & $\begin{array}{c}\text { Percent of DB Plans } \\
\text { Converting Cash Balance* }\end{array}$ & $\begin{array}{l}\text { Percent of Firms } \\
\text { with a DB Plan* }\end{array}$ & $\begin{array}{l}\text { Employer to Employer } \\
\text { Rate }\end{array}$ & $\begin{array}{c}\text { Percent of } \\
\text { Employees Over } 45\end{array}$ & $\begin{array}{l}\text { Unemployment } \\
\text { Rate }\end{array}$ \\
\hline \multicolumn{6}{|l|}{ Manufacturing } \\
\hline Durable & 23.0 & 66 & 1.8 & 33.0 & 3.4 \\
\hline \multicolumn{6}{|l|}{ Manufacturing } \\
\hline Non-Durable & 18.6 & 81 & 2.0 & 32.3 & 4.7 \\
\hline Transportation & 14.3 & 80 & 1.3 & 35.2 & 4.0 \\
\hline $\begin{array}{l}\text { Utilities and Sanitation } \\
\text { Services }\end{array}$ & 24.2 & 90 & 1.9 & 38.8 & 2.4 \\
\hline Communication & 50.0 & 67 & 1.7 & 29.8 & 2.4 \\
\hline $\begin{array}{l}\text { Finance, Insurance, } \\
\text { and Real Estate }\end{array}$ & 26.0 & 72 & 2.5 & 31.9 & 2.5 \\
\hline $\begin{array}{l}\text { Technology, Business } \\
\text { Services }\end{array}$ & 54.5 & 50 & 4.3 & 26.2 & 2.9 \\
\hline Wholesale Trade & 22.2 & 83 & 2.4 & 30.7 & 3.7 \\
\hline Retail Trade & 28.6 & 49 & 3.8 & 21.1 & 6.0 \\
\hline Mining & 0.0 & 79 & 2.4 & 34.4 & 3.2 \\
\hline Construction & 0.0 & 25 & 3.5 & 28.4 & 7.5 \\
\hline
\end{tabular}

*S\&P 500 firms $\quad$ Source: Compustat, author's tabulations from annual 10K report filings of S\&P 500 firms, Bureau of Labor Statistics 
Table 3. Correlations of Industry Level Data on Employee Characteristics and Plan Characteristics

\begin{tabular}{|c|c|c|c|c|c|}
\hline & $\begin{array}{c}\text { Percent of DB Plans } \\
\text { Converting to Cash Balance }\end{array}$ & $\begin{array}{l}\text { Percent of Firms } \\
\text { with a DB Plan }\end{array}$ & $\begin{array}{c}\text { Employer to Employer } \\
\text { Rate }\end{array}$ & $\begin{array}{c}\text { Percent of } \\
\text { Employees Over } 45\end{array}$ & $\begin{array}{l}\text { Unemployment } \\
\text { Rate }\end{array}$ \\
\hline $\begin{array}{l}\text { Percent of DB Plans } \\
\text { Converting to Cash } \\
\text { Balance Plans }\end{array}$ & 1.000 & -.609 & 0.438 & -.507 & -.258 \\
\hline $\begin{array}{l}\text { Percent of Firms } \\
\text { with a DB Plan }\end{array}$ & -.609 & 1.000 & -.751 & 0.875 & -.302 \\
\hline $\begin{array}{l}\text { Employer to } \\
\text { Employer Rate }\end{array}$ & 0.438 & -.751 & 1.000 & -.772 & 0.267 \\
\hline $\begin{array}{l}\text { Percent of Employees } \\
\text { Over } 45\end{array}$ & -.507 & 0.875 & -.772 & 1.000 & -.545 \\
\hline Unemployment Rate & -.258 & -.302 & 0.267 & -.545 & 1.000 \\
\hline
\end{tabular}

Source: Compustat, author's tabulations from annual 10K report filings of S\&P 500 firms, Bureau of Labor Statistics 
Table 4. Determinants of the Probability that a Firm Converted its Traditional DB Pension to a Cash Balance Plan*

\begin{tabular}{|c|c|c|c|c|}
\hline & \multicolumn{2}{|c|}{1998} & \multicolumn{2}{|c|}{1994} \\
\hline & $\begin{array}{c}\text { w/o industry } \\
\text { dummies }\end{array}$ & $\begin{array}{l}\text { w/ industry } \\
\text { dummies }\end{array}$ & $\begin{array}{c}\text { w/o industry } \\
\text { dummies }\end{array}$ & $\begin{array}{l}\text { w/ industry } \\
\text { dummies }\end{array}$ \\
\hline percent of firms w/ db plan & $\begin{array}{l}0.001 \\
(0.38)\end{array}$ & $\begin{array}{l}-0.004 \\
(0.00)\end{array}$ & $\begin{array}{l}-0.001 \\
(0.27)\end{array}$ & $\begin{array}{l}-0.049 \\
(8.19)\end{array}$ \\
\hline employer to employer rate & $\begin{array}{l}0.052 \\
(1.51)\end{array}$ & $\begin{array}{l}0.063 \\
(1.87)\end{array}$ & $\begin{array}{l}0.099 \\
(1.81)\end{array}$ & $\begin{array}{l}0.130 \\
(2.44)\end{array}$ \\
\hline labor force over 45 & $\begin{array}{l}-0.015 \\
(1.08)\end{array}$ & $\begin{array}{l}-0.835 \\
(0.37)\end{array}$ & $\begin{array}{l}-0.001 \\
(0.04)\end{array}$ & $\begin{array}{l}-0.030 \\
(2.26)\end{array}$ \\
\hline unemployment rate & $\begin{array}{l}-0.056 \\
(1.83)\end{array}$ & $\begin{array}{l}-4.10 \\
(0.51)\end{array}$ & $\begin{array}{l}-0.038 \\
(1.45)\end{array}$ & $\begin{array}{c}-1.66 \\
(31.34)\end{array}$ \\
\hline log of plan assets & $\begin{array}{l}0.054 \\
(3.18)\end{array}$ & $\begin{array}{c}0.04 \\
(2.88)\end{array}$ & $\begin{array}{l}0.055 \\
(2.91)\end{array}$ & $\begin{array}{l}0.047 \\
(2.77)\end{array}$ \\
\hline funding percentage & $\begin{array}{l}-0.000 \\
(0.03)\end{array}$ & $\begin{array}{l}-0.000 \\
(0.19)\end{array}$ & $\begin{array}{l}0.000 \\
(0.28)\end{array}$ & $\begin{array}{l}0.000 \\
(0.16)\end{array}$ \\
\hline number of observations & 317 & 317 & 259 & 259 \\
\hline pseudo R-squared & 0.059 & 0.097 & 0.066 & 0.109 \\
\hline
\end{tabular}

* Marginal effects are presented with t-statistics shown in parentheses. 


\section{Endnotes}

1 A review of the literature on the demand for pensions by workers and firms can be found in Even and MacPherson (2001) and Gustman, Mitchell, and Steinmeier (1994).

2 Analyses of the role of DB pensions in the labor market can be found in Lazear (1979), Hutchens (1989), Mitchell (1990), Even and Macpherson (1992), and Friedberg and Owyang (2002).

3 This assumes forward-looking, rational workers. If individuals suffer from lack of selfcontrol, they may appreciate either a DB or DC pension as a commitment mechanism (Laibson, Repetto, and Tobacman, 1998). In the same vein, while DC plans offer individuals control over their investments, some may prefer that their employers make those decisions on their behalf (Choi, et al., 2001).

${ }^{4}$ Examples of this research include Poterba, Venti and Wise (2001, 1995), Pence (2002), and Engen, Gale and Scholz (1994).

${ }^{5}$ These include Gustman and Steinmeier (1992), Ippolito (1995) and Kruse (1995) who all used data covering the first half of the 1980s from the Form 5500 filed by private pension plans with the Department of Labor.

${ }^{6}$ What employees actually have a right to if they leave the firm is a measure called the accumulated benefit obligation ( $\mathrm{ABO})$, often referred to as the termination benefit. In a cash balance plan, the $\mathrm{ABO}$ and the $\mathrm{PBO}$ are not very different. Without going into technical detail, under a traditional $\mathrm{DB}$ plan, the $\mathrm{ABO}$ is much less than the $\mathrm{PBO}$ until the employee is close to retirement age. This is a result of the back-loading of benefits. Charting the $\mathrm{ABO}$ under each type of plan would therefore accentuate the relative accrual patterns shown in Chart 1 . We 
choose to illustrate the different accrual patterns using the PBO as we will use it later in the analysis.

${ }^{7}$ Defining such a measure is somewhat problematic given that unemployed workers are attributed to the industry where they last worked, though they might find employment in a different sector. 